\title{
Stress analysis of the through arch bridge double boom system
}

\author{
Ke-xin $\mathrm{Li}^{1, \mathrm{a}^{*}, \text { Xiao-jun Ning }}{ }^{2, \mathrm{~b}}$ \\ ${ }^{1}$ Faculty of Civil Engineering and Mechanics, Kunming University of Science and Technology, \\ Kunming, China \\ a331345736@qq.com, b616672033@qq.com, ${ }^{*}$ corresponding author
}

Keywords: double boom system, suddenly broken, the internal force response

Abstract:This paper by analyzing the existing double boom system, and combined with engineering examples the through arch bridge in the mobile load that is the role of vehicle load force each boom situation. Studied double boom system in response to vehicle load internal forces, also studied a boom when suddenly broken rib effect on belongs. We came to the conclusion, in the moving load short boom force more favorable than long boom, and boom suddenly off, the internal force will fluctuate internal force near the Arch Bridge under operational conditions effect.

\section{Introduction}

Arch bridge is a highway bridge is one of the most widely used, in the vertical plane, arch bridge arch rib under the structure of the main load and load transfer to the substructure. The boom is the main force component of the arch bridge, that is, the load of the bridge deck system and the vehicle's live load. It is through the arch rib and the bridge deck system. So the reliability and durability of the bridge structure are very important.

\section{Double boom system}

In recent years, while the through arch bridge rapid development, the bridge collapse accident due to the boom suddenly broken frequently at home and abroad. In order to prevent such incidents from happening again, the researchers tried to introduce double boom system in the arch design. The so-called double suspender system, The so-called dual-boom system, which is the original of a hanging point setting a boom, change to a lifting point setting two booms, this approach can make the deck stiffness, the anchorage size is reduced and the phenomenon of stress concentration. Double boom system according to the geometry of the different parallel double boom arrangement and cross double boom arrangement.

Theoretical and experimental results show that, whether the parallel double suspender structure or cross double suspender structure, the stress level is equal to two boom that stress the relationship $\sigma_{1}=\sigma_{2}$ set up, At the same time, the two boom in the same external natural environment, At the same time, the dead load and live load are the same in the same external environment, which can be found that the life of two booms is not different. The other one is failure, and the other is broken. The above analysis shows: a simple ordinary double boom arrangement does not guarantee the safe operation of the structure.

\section{Analysis of the through arch bridge boom in the instance}

A bridge is a prestressed concrete girder and arch combination through arch bridge. The arch axis of arch bridge is two times parabola. Its calculation span is 43.43 meters, and the atio of rise to span is 1 /4.Bridge deck design two-way four lane Motor vehicle lane width $19.0 \mathrm{~m}$, separated by a wide 2 $\times 2.5 \mathrm{~m}$, non motorized vehicle lane width of $2 \times 4.0 \mathrm{~m}, 2 \times 3.75 \mathrm{~m}$ width of the sidewalk, the total width of the bridge 40 meters. The design load for the automotive is -20 level, the -100 of the trailer, and the crowd load $3.5 \mathrm{KN} / \mathrm{m}^{\wedge} 2$.

The bridge superstructure reinforced and prestressed concrete girder tied arch combination through arch system. The arch rib is a rectangular cross section with no hinge arch, the width of the cross 
section is 2.2 meters ,a width not change with the arch axis,and the width is 1.4 meters, Rib-sectional thickness with arch axis changes according to a parabolic law,Arch foot thick 1.80 meters,Material for reinforced concrete.Cross bridge is arranged as an open type arch bridge, and the spacing of the two pieces of arch rib is 21.50 meters. Prestressed concrete production system The beam section of the system is a rectangular cross section, and the other is box section, the section width is $2.5 \mathrm{~m}$, the section height is $2.0 \mathrm{~m}$. Tie beam base frequency $\mathrm{f}=5.18 \mathrm{HZ}$, impact coefficient a $=0.275$. The bridge has 7 pairs of boom and the center distance of the boom is 5.0m.To facilitate the calculations show, for the boom are numbered, numbered as Fig 1.

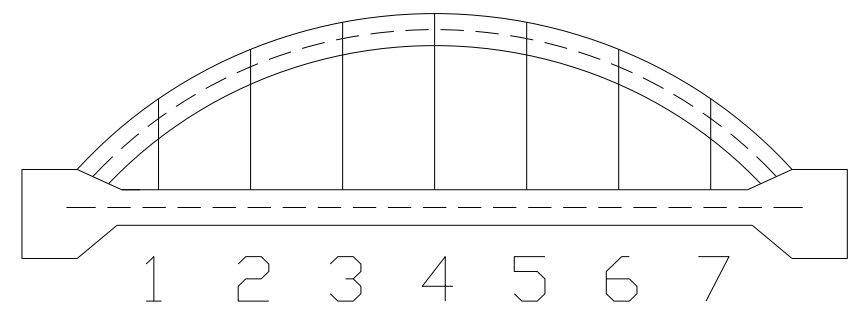

Fig. 1

\section{Boom internal force response}

Build the bridge Midas model, because the main dynamic load is the vehicle load, so the vehicle load is simplified as the ideal load, vehicle load as a centralized force uniform motion of load on the deck. In order to determine that the vehicle load boom force the most disadvantaged, the end, 1/4 cross, cross in the middle of the location of the three boom of the calculation of the data were compared, that figure in the 1 (short), 3 (in the middle), 4 (long boom) boom listed in table 1.

Table 1 The axial force response of the boom under vehicle load

\begin{tabular}{|r|c|c|c|}
\hline & 1 (short boom) & 3 (in the middle boom) & 4 (long boom) \\
\hline $\begin{array}{c}\text { The maximum } \\
\text { axial force }[\mathrm{KN}]\end{array}$ & 2800 & 1150 & 750 \\
\hline $\begin{array}{r}\text { The minimum } \\
\text { axial force [KN] }\end{array}$ & -2100 & -1250 & -2000 \\
\hline
\end{tabular}

The above table shows that, the internal force response of the bridge under the action of vehicle load is greater than that of 3 and 4. Under the vehicle load, the internal force response of the bridge under the bridge's 1 is greater than that of the 3 and 4 . That is, the force of short boom is more unfavorable.

\section{The suspender sudden broken effect on arch rib}

By the known, under the vehicle load, short Arch Bridge Suspender Force more adverse. the following will analyze the 1st step off lever effect on rib.

The bridge each hanging point has two slings $\mathrm{F}$ cable and $\mathrm{S}$ cable, now to No. $1 \mathrm{~F}$ cable suspender sudden broken.

The working conditions of the bridge are as table 2 . 
Table 2 The working conditions of the bridge

\begin{tabular}{|c|c|c|}
\hline $\begin{array}{l}\text { Condition } 1 \text {; operating } \\
\text { conditions }\end{array}$ & $\begin{array}{l}\text { Condition 2; broken } \\
\text { cable conditions }\end{array}$ & $\begin{array}{r}\text { Condition 3; rear } \\
\text { working conditions }\end{array}$ \\
\hline $\begin{array}{l}\text { Before the bridge } \\
\text { opened to traffic, according } \\
\text { to the design of F cable, } \mathrm{S} \\
\text { cable, the difference of the } \\
\text { cross-sectional area, } \\
\text { ultra-tensioning cable in } \\
\text { order to ensure that its } \mathrm{F} S \\
\text { cable internal forces are } \\
\text { equal, that is. } S_{F}=S_{S} \text {. }\end{array}$ & $\begin{array}{l}\text { F cable sudden broken } \\
\text { load effects considered } \\
\text { dead load and live load and } \\
\text { step off the impact } \\
\text { force. Dead load including } \\
\text { horizontal beam weight as } \\
\text { well as the second phase of } \\
\text { dead load and live load } \\
\text { mainly consists of the } \\
\text { vehicle load, vehicle } \\
\text { impact load and the crowd } \\
\text { load and non motor vehicle } \\
\text { load, plus F cable suddenly } \\
\text { broken impact load. }\end{array}$ & $\begin{array}{l}\text { F cable rear suspender } \\
\text { load effects such as dead } \\
\text { load and live load of the } \\
\text { axial force, break from the } \\
\text { cable with a hanging point } \\
\text { s cable and other lifting } \\
\text { point of suspender } \\
\text { undertakes the task of } \\
\text { bridge structure. }\end{array}$ \\
\hline
\end{tabular}

\section{The effect of broken cable on the axial force of arch rib}

The axial force of arch rib for $1 \mathrm{~F}$ cable suspender sudden broken change, cable break side arch rib axis force changes in the value of relative on the other side of the larger, so following table lists the broken rope hanging position each side Ribs in case 1, case 2, condition 3 under axial force value.

Table $3 \mathrm{~F}$ cable suspender sudden broken cable caused by the fault of side arch rib axial force variation table (unit: $\mathrm{KN}$ )

\begin{tabular}{|c|c|c|c|c|c|c|c|c|}
\hline \multirow{2}{*}{$\begin{array}{l}\text { Ribs } \\
\text { transver } \\
\text { se to the } \\
\text { position }\end{array}$} & \multirow[b]{2}{*}{$\begin{array}{l}\text { Cond } \\
\text { ition }\end{array}$} & \multicolumn{7}{|c|}{ Ribs along the bridge to the position } \\
\hline & & $\begin{array}{l}\text { 1han } \\
\text { ging } \\
\text { point }\end{array}$ & $\begin{array}{l}\text { 2han } \\
\text { ging } \\
\text { point }\end{array}$ & $\begin{array}{l}\text { 3han } \\
\text { ging } \\
\text { point }\end{array}$ & $\begin{array}{l}\text { 4han } \\
\text { ging } \\
\text { point }\end{array}$ & $\begin{array}{l}\text { 5han } \\
\text { ging } \\
\text { point }\end{array}$ & $\begin{array}{r}\text { 6hang } \\
\text { ing point }\end{array}$ & $\begin{array}{l}\text { 7hangi } \\
\text { ng point }\end{array}$ \\
\hline \multirow{4}{*}{$\begin{array}{c}\text { Ribs } \\
\text { broken } \\
\text { cable } \\
\text { side }\end{array}$} & 1 & -12090 & -10480 & -9319 & -8578 & -9319 & -10480 & -12090 \\
\hline & $\begin{array}{c}2 \\
(\operatorname{maxi} \\
\text { mum })\end{array}$ & -12458 & -10752 & -9526 & -8784 & -9526 & -10752 & -12458 \\
\hline & $\begin{array}{c}2 \\
(\operatorname{mini} \\
\text { mum })\end{array}$ & -11797 & -10241 & -9185 & -8407 & -9185 & -10241 & -11797 \\
\hline & 3 & -12112 & -10491 & -9331 & -8589 & -9331 & -10491 & -12112 \\
\hline
\end{tabular}

From the above table 3, the stress value of the arch rib can fluctuate around the axial force near the working condition 1 .

the effect of cable breaking on the shear force of the arch rib

The shear of arch rib for $1 \mathrm{~F}$ cable suspender sudden broken change, cable break side arch rib shear changes in the value of relative on the other side of the larger, so following table lists the broken rope hanging position each side Ribs in case 1, case 2, condition 3 under shear value. 
Table $4 \mathrm{~F}$ cable suspender sudden broken cable caused by the fault of side arch rib shear variation table (unit: KN)

\begin{tabular}{|c|c|c|c|c|c|c|c|c|}
\hline \multirow{2}{*}{$\begin{array}{l}\quad \text { Ribs } \\
\text { transver } \\
\text { se to the } \\
\text { position }\end{array}$} & \multirow[b]{2}{*}{$\begin{array}{l}\text { Cond } \\
\text { ition }\end{array}$} & \multicolumn{7}{|c|}{ Ribs along the bridge to the position } \\
\hline & & $\begin{array}{l}\text { 1han } \\
\text { ging } \\
\text { point }\end{array}$ & $\begin{array}{l}\text { 2han } \\
\text { ging } \\
\text { point }\end{array}$ & $\begin{array}{l}\text { 3han } \\
\text { ging } \\
\text { point }\end{array}$ & $\begin{array}{l}\text { 4han } \\
\text { ging } \\
\text { point }\end{array}$ & $\begin{array}{l}\text { 5han } \\
\text { ging } \\
\text { point }\end{array}$ & $\begin{array}{l}\text { 6hang } \\
\text { ing point }\end{array}$ & $\begin{array}{l}\text { 7hangi } \\
\text { ng point }\end{array}$ \\
\hline \multirow{4}{*}{$\begin{array}{l}\text { Ribs } \\
\text { broken } \\
\text { cable } \\
\text { side }\end{array}$} & 1 & 251.8 & 56.4 & 84 & -203.7 & 84 & 56.4 & 251.8 \\
\hline & $\begin{array}{c}2 \\
(\operatorname{maxi} \\
\operatorname{mum})\end{array}$ & 219.4 & 38.6 & 69.8 & -215.2 & 69.8 & 38.6 & 219.4 \\
\hline & $\begin{array}{c}2 \\
(\text { mini } \\
\text { mum })\end{array}$ & 298.2 & 72.5 & 97.7 & -191.2 & 97.7 & 72.5 & 298.2 \\
\hline & 3 & 259.7 & 58.4 & 85.2 & -204.9 & 85.2 & 58.4 & 259.7 \\
\hline
\end{tabular}

From the above table 4, the stress value of the arch rib can fluctuate around the shear near the working condition 1 .

the effect of cable breaking on the displacement force of the arch rib

The displacement of arch rib for $1 \mathrm{~F}$ cable suspender sudden broken change, cable break side arch rib displacement changes in the value of relative on the other side of the larger, so following table lists the broken rope hanging position each side Ribs in case 1, case 2, condition 3 under displacement value.

Table $5 \mathrm{~F}$ cable suspender sudden broken cable caused by the fault of side arch rib displacement variation table (unit: $\mathrm{KN}$ )

\begin{tabular}{|c|c|c|c|c|c|c|c|c|}
\hline \multirow{2}{*}{$\begin{array}{l}\text { Ribs } \\
\text { transver } \\
\text { se to the } \\
\text { position }\end{array}$} & \multirow[b]{2}{*}{$\begin{array}{l}\text { Cond } \\
\text { ition }\end{array}$} & \multicolumn{7}{|c|}{ Ribs along the bridge to the position } \\
\hline & & $\begin{array}{l}\text { 1han } \\
\text { ging } \\
\text { point }\end{array}$ & $\begin{array}{l}\text { 2han } \\
\text { ging } \\
\text { point }\end{array}$ & $\begin{array}{l}\text { 3han } \\
\text { ging } \\
\text { point }\end{array}$ & $\begin{array}{l}\text { 4han } \\
\text { ging } \\
\text { point }\end{array}$ & $\begin{array}{l}\text { 5han } \\
\text { ging } \\
\text { point }\end{array}$ & $\begin{array}{l}\text { 6hang } \\
\text { ing point }\end{array}$ & $\begin{array}{l}\text { 7hangi } \\
\text { ng point }\end{array}$ \\
\hline \multirow{4}{*}{$\begin{array}{l}\text { Ribs } \\
\text { broken } \\
\text { cable } \\
\text { side }\end{array}$} & 1 & -0.7 & -5.1 & -7.6 & -9.8 & -7.6 & -5.1 & -0.7 \\
\hline & $\begin{array}{c}2 \\
(\operatorname{maxi} \\
\text { mum })\end{array}$ & -0.8 & -6.1 & -9.2 & -11.7 & -9.2 & -6.1 & -0.8 \\
\hline & $\begin{array}{c}2 \\
(\operatorname{mini} \\
\text { mum })\end{array}$ & -0.6 & -4.2 & -5.8 & -88.5 & -5.8 & -4.2 & -0.6 \\
\hline & 3 & -0.7 & -5.1 & -7.5 & -9.6 & -7.5 & -5.1 & -0.7 \\
\hline
\end{tabular}

From the above table 5, the stress value of the arch rib can fluctuate around the displacement near the working condition 1.

\section{Conclusion}

After the above comparison and analysis, we can easily draw two general conclusions

1, The internal force response of the arch bridge's 1 boom is greater than that of the 3 and 4 boom, which is located at the end of the arch rib, the short boom is more unfavorable.

2 , the suspender sudden broken, the internal force in the status of the 1(operating) rib arch bridge near the value of the internal force under the fluctuation. 


\section{Acknowledgements}

This work was financially supported by the National Science Foundation of China (51068012) an $d$ the Yunnan Province Communications DepartmentScience and Technology Program (2013(c)07).

\section{References}

[1] Kong Qingkai, Large-span arch bridge structure behavior of short boom[D], Cheng du. 2003.

[2] Li Yuanbin, Arch boom mechanical behavior and degradation Injury[D], Shang hai, Tongji University, 2008.

[3] Chen Bin, Luo Tejun, Research on the boom system of middle and lower bearing arch bridge[J]., Sichuan architecture, 2002.4 